\title{
Diagnostic value of the serum folate assay
}

\author{
J. FORSHAW AND LILIAN HARWOOD
}

\author{
From the Haematology Laboratory, Sefton General Hospital, Liverpool
}

SYNOPSIS The diagnostic value of the serum folate assay has been assessed in 90 patients, each of whom had a macrocytic anaemia and a low serum vitamin $\mathbf{B}_{12}$ level. Twenty-nine $(32 \%)$ patients were found to have anaemia due primarily to folate deficiency. The cause of the low serum vitamin $B_{12}$ levels is uncertain in the $22(25 \%)$ patients with normal or borderline vitamin $B_{12}$ absorption. The effect of folic acid therapy was studied in four of these patients, and in each case the serum vitamin $B_{12}$ rose slowly to a normal level.

The serum folate was low in only four $(7 \cdot 5 \%)$ of the 54 patients with pernicious anaemia, and the levels rose to normal on treatment with vitamin $B_{12}$ alone. A high serum folate occurred in eight $(15 \%)$ pernicious anaemia patients. A normal serum folate indicated the diagnosis of pernicious anaemia or megaloblastic anaemia following partial gastrectomy. However, a normal serum folate and a very low vitamin $B_{12}$ level was found in two patients with idiopathic steatorrhoea.

It is concluded that the serum folate assay is a valuable routine test in patients who have a macrocytic anaemia and low serum vitamin $\mathbf{B}_{12}$. A low folate level makes the diagnosis of pernicious anaemia unlikely and is a strong indication for full investigation of small intestinal function.

The significance of the serum and red cell folate concentration has been reviewed recently by Chanarin (1969). The serum folate was low in one third of 877 'normoblastic' hospital patients, whereas the red cell folate was low in only $17 \%$ of 161 'normoblastic' patients with a low serum folate level. On the other hand, the red cell folate was low in $60 \%$ of 161 patients with pernicious anaemia, but there was a low serum folate in only $10 \%$ of 361 pernicious anaemia patients. These observations show that the red cell folate gives a better assessment of the body folate status than does the serum folate, provided that vitamin $\mathbf{B}_{12}$ deficiency has been excluded. However, some $47 \%$ of patients with megaloblastic anaemia due to folate deficiency have a low serum vitamin $\mathbf{B}_{12}$ level (Mollin, Waters, and Harriss, 1962), and this may complicate the detection of vitamin $B_{12}$ deficiency. The serum folate, therefore, should be more valuable than the red cell folate in the investigation of patients with megaloblastic anaemia and low serum vitamin $B_{12}$ levels. The purpose of the present paper is to re-assess the diagnostic value of routine serum folate assays in such patients.

\section{Materials and Methods}

Ninety patients were studied, all of whom had a macrocytic blood film and a serum vitamin $B_{12}$ level below $150 \mathrm{pg}$ per $\mathrm{ml}$. The haemoglobin level was Received for publication 5 August 1970. above $11.0 \mathrm{~g}$ per $100 \mathrm{ml}$ in four patients, but the others were moderately or severely anaemic. The bone marrow was examined in 89 patients, and was overtly megaloblastic in 85 . The final diagnoses were: pernicious anaemia 54 patients $(41 \mathrm{~F}, 13 \mathrm{M})$; nutritional folate deficiency 18 patients $(12 \mathrm{~F}, 6 \mathrm{M})$; idiopathic steatorrhoea 12 patients $(7 \mathrm{~F}, 5 \mathrm{M})$; partial gastrectomy four patients $(2 \mathrm{~F}, 2 \mathrm{M})$; anticonvulsant therapy one patient (M); unknown aetiology one patient (F).

The intestinal absorption of $0.5 \mu \mathrm{g}$ vitamin $\mathrm{B}_{12}$, labelled with $0.5 \mu \mathrm{C}{ }^{57} \mathrm{Co}$, was measured in every case. The absorbed radioactivity was counted in the serum (Harwood and Forshaw, 1967) in 66 patients, and in a 24-hour collection of urine (Schilling, 1953) in the other 24. Secretion of intrinsic factor was stimulated by either histamine $0.4 \mathrm{mg}$ or pentagastrin $6.0 \mu \mathrm{g}$ per kilogram of body weight. In 43 of the 70 patients with impaired absorption the test was repeated with an oral dose of $60 \mathrm{mg}$ intrinsic factor preparation (Armour). A result below 0.5\% of administered radioactivity per litre of serum or $10 \%$ in a 24-hour collection of urine indicates impaired absorption.

The levels of serum vitamin $B_{12}$ and folate were measured by microbiological assay using Lactobacillus leichmanii (Matthews, 1962) and Lactobacillus casei (Spray, 1964) respectively. In our laboratory the normal range for the serum vitamin $B_{12}$ level is 150 to $850 \mathrm{pg}$ per $\mathrm{ml}$ and for the folate $2 \cdot 1$ to $10 \cdot 0 \mathrm{ng}$ per $\mathrm{ml}$. 
Serum intrinsic factor blocking antibody was assayed by the coated charcoal method (Gottlieb, Lau, Wasserman, and Herbert, 1965) and gastric parietal cells antibody by the immunofluorescent technique (Taylor, Roitt, Doniach, Couchman, and Shapland, 1962).

\section{Results}

RELATIONSHIP BETWEEN SERUM FOLATE LEVELS AND VITAMIN B 12 ABSORPTION

In Figure 1 the results of the serum folate assays and the vitamin $\mathbf{B}_{12}$ absorption tests are compared. The 56 patients with a normal or raised serum folate had impaired vitamin $\mathbf{B}_{12}$ absorption. These included 50 patients with pernicious anaemia, two patients with idiopathic steatorrhoea, and three patients who had had a partial gastrectomy. In the other patient, who has been described previously (Forshaw, 1969), the impaired vitamin $B_{12}$ absorption was corrected by vitamin $\mathrm{B}_{12}$ and the diagnosis was not certain.

There were 34 patients with a low serum folate, 20 of whom had normal vitamin $B_{12}$ absorption. This group of patients included 16 with nutritional folate deficiency, three with idiopathic steatorrhoea, and one on anticonvulsant therapy. Of the 14 patients with a low serum folate and abnormal vitamin $\mathbf{B}_{12}$ absorption, seven had idiopathic steatorrhoea, four pernicious anaemia, one a partial gastrectomy, and there were two with nutritional folate deficiency in whom vitamin $\mathbf{B}_{12}$ absorption

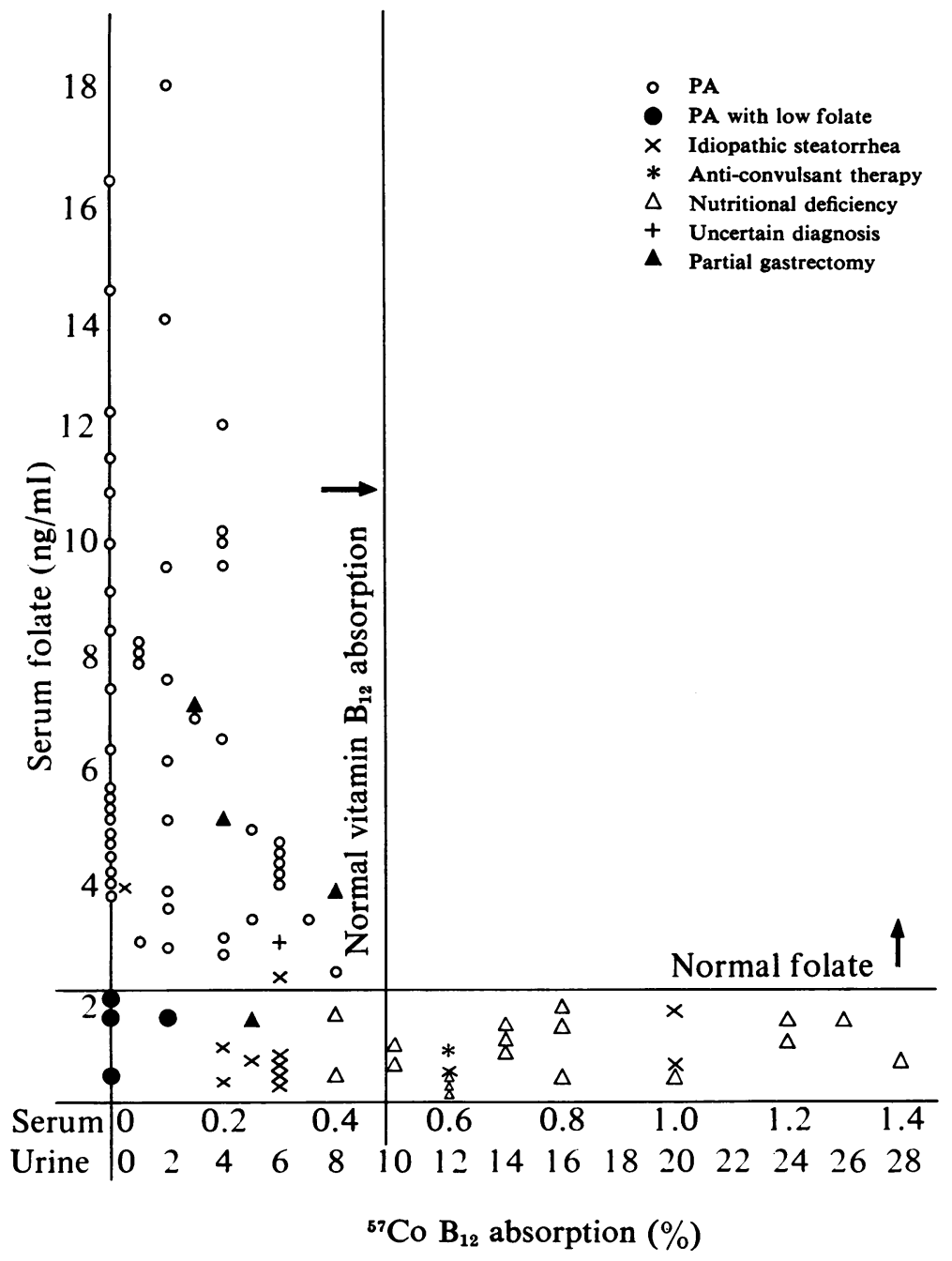

Fig. 1. Graph to show the relationship between serum folate and ${ }^{57} \mathrm{Co}$ vitamin $B_{12}$ absorption in 90 cases of megaloblastic anaemia. 
was in the borderline range $(0 \cdot 4 \% /$ litre serum).

\section{RELATIONSHIP BETWEEN SERUM FOLATE AND} VITAMIN B 12 LEVELS

This is illustrated in Figure 2. None of the 56 patients with a normal or raised serum folate had a serum vitamin $B_{12}$ level above $90 \mathrm{pg}$ per $\mathrm{ml}$, and only one had a level above $70 \mathrm{pg}$ per $\mathrm{ml}$. The vitamin $\mathbf{B}_{12}$ levels were more widely scattered in the patients with a low serum folate, but 15 of the 28 patients with either idiopathic steatorrhoea or nutritional folate deficiency in this group had a vitamin $\mathbf{B}_{\mathbf{1 2}}$ level below $90 \mathrm{pg}$ per ml. In four patients with nutritional folate deficiency and normal vitamin $\mathrm{B}_{12}$ absorption, the serum vitamin $B_{12}$ levels were 45 , 45,30 , and $20 \mathrm{pg}$ per $\mathrm{ml}$ respectively
PERNICIOUS ANAEMIA

The mean serum folate level was $6.6 \mathrm{ng}$ per $\mathrm{ml}$ in the 54 pernicious anaemia patients, which is significantly higher than the mean level of $4.7 \mathrm{ng}$ per $\mathrm{ml}$ in control subjects. However, the levels ranged from 0.5 to $18.1 \mathrm{ng}$ per $\mathrm{ml}$, being above $10.0 \mathrm{ng}$ in eight $(15 \%)$ and below $2 \cdot 1 \mathrm{ng}$ in four $(7.5 \%)$ patients. The details of the patients with a low serum folate are shown in Table I. They were all multiparous females, three of whom had gastric parietal cell antibodies in the serum, but none had intrinsic factor antibodies. In the patient with no antibodies, the diagnosis of pernicious anaemia depended on impaired vitamin $\mathrm{B}_{12}$ absorption which was corrected by intrinsic factor. In each case vitamin $B_{12}$ therapy alone produced a complete haematological recovery,

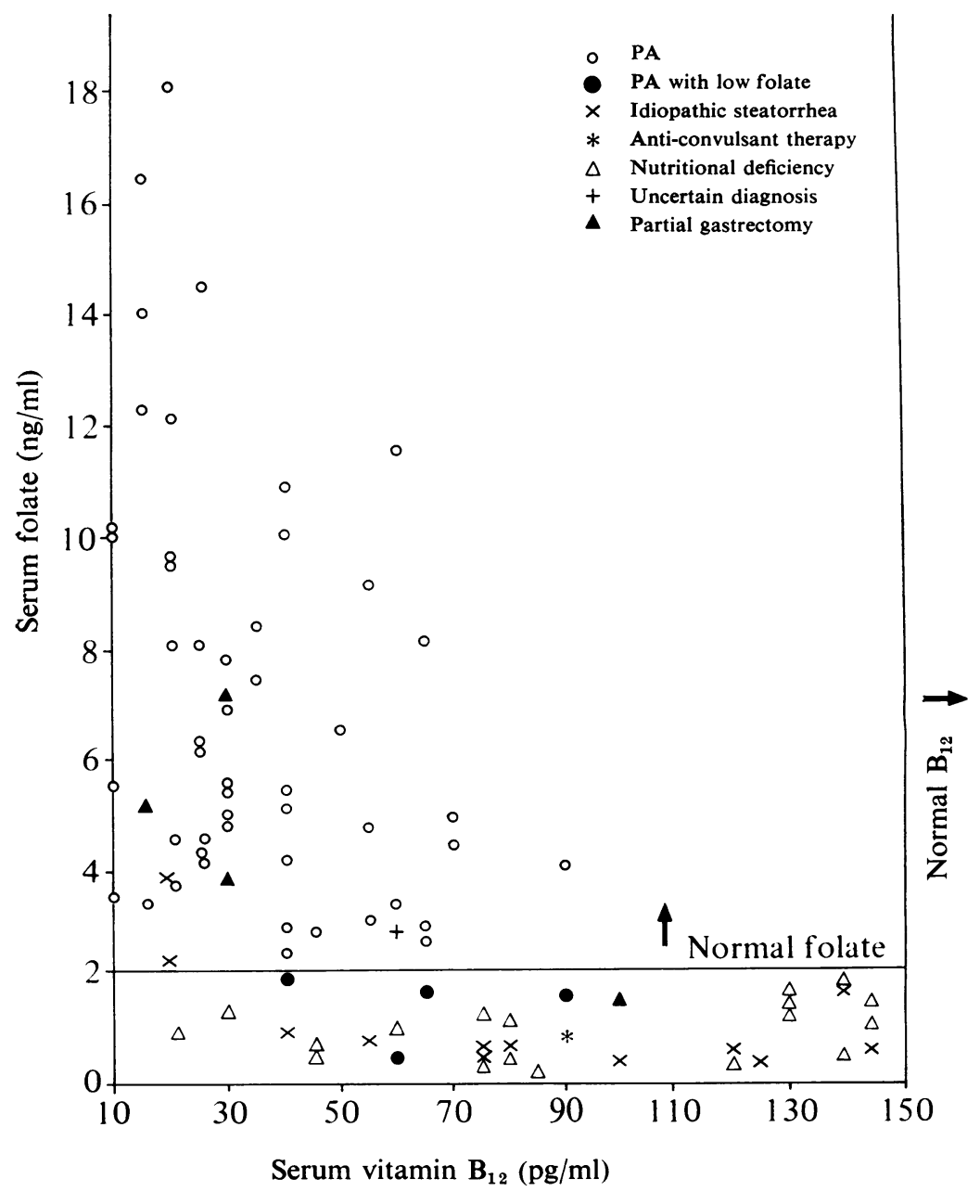

Fig. 2. Graph to show the relationship between serum folate and serum vitamin $B_{12}$ in 90 cases of megaloblastic anaemia. 
and the serum folates rose to a normal level.

\section{IDIOPATHIC STEATORRHOEA}

We have used this term rather than coeliac disease, as we were unable to do a small intestinal mucosal biopsy in every case to confirm the diagnosis of coeliac disease. However, radiographs of the small bowel were taken in each case and they showed no evidence of any other cause for the steatorrhoea.

Details of these 12 patients are given in Table II. The serum folate was low in 10 patients with a mean level of $0.7 \mathrm{ng}$ per $\mathrm{ml}$. The folate level was normal

\begin{tabular}{|c|c|c|c|c|c|c|c|c|c|c|c|}
\hline \multirow[t]{2}{*}{$\begin{array}{l}\text { Patient } \\
\text { No. }\end{array}$} & \multirow[t]{2}{*}{$\operatorname{Sex}$} & \multirow[t]{2}{*}{ Age } & \multirow[t]{2}{*}{$\begin{array}{l}H b \\
(g / m l l 00)\end{array}$} & \multirow{2}{*}{$\begin{array}{l}\text { Serum } \\
\text { Vitamin } B_{12} \\
(\mathrm{pg} / \mathrm{ml})\end{array}$} & \multicolumn{2}{|c|}{ Serum Folate $(\mathrm{ng} / \mathrm{ml})$} & \multicolumn{2}{|c|}{$\begin{array}{l}\text { Vitamin } B_{12} \text { Absorption } \\
\text { ( } \% \text { dose per litre serum) }\end{array}$} & \multicolumn{2}{|c|}{ Serum Antibodies } & \multirow[t]{2}{*}{$\begin{array}{l}\text { No. of } \\
\text { Pregnancies }\end{array}$} \\
\hline & & & & & $\begin{array}{l}\text { Before } \\
\text { Vitamin } B_{12} \\
\text { Therapy }\end{array}$ & $\begin{array}{l}\text { After } \\
\text { Vitamin } B_{12} \\
\text { Therapy }\end{array}$ & $\begin{array}{l}\text { Histamine or } \\
\text { Pentagastrin }\end{array}$ & $\begin{array}{l}\text { Intrinsic } \\
\text { Factor }\end{array}$ & $\begin{array}{l}\text { Gastric } \\
\text { Parietal Cell }\end{array}$ & $\begin{array}{l}\text { Intrinsic } \\
\text { Factor }\end{array}$ & \\
\hline $\begin{array}{l}1 \\
2 \\
3 \\
4\end{array}$ & $\begin{array}{l}\mathbf{F} \\
\mathbf{F} \\
\mathbf{F} \\
\mathbf{F}\end{array}$ & $\begin{array}{l}74 \\
37 \\
71 \\
61\end{array}$ & $\begin{array}{r}11 \cdot 0 \\
8.5 \\
6.5 \\
5.7\end{array}$ & $\begin{array}{l}60 \\
90 \\
65 \\
40\end{array}$ & $\begin{array}{l}0.5 \\
1 \cdot 6 \\
1 \cdot 7 \\
2.0\end{array}$ & $\begin{array}{l}4 \cdot 1 \\
3 \cdot 0 \\
2 \cdot 5 \\
3 \cdot 2\end{array}$ & $\begin{array}{l}0.0 \\
0.1 \\
0.0 \\
0.0\end{array}$ & 0.8 & $\begin{array}{l}- \\
+ \\
+ \\
+\end{array}$ & $\begin{array}{l}- \\
- \\
-\end{array}$ & $\begin{array}{r}4 \\
2 \\
2 \\
13\end{array}$ \\
\hline
\end{tabular}

Table I Details of patients with pernicious anaemia and low serum folate levels

\begin{tabular}{|c|c|c|c|c|c|c|c|c|c|c|c|}
\hline \multirow[t]{2}{*}{$\begin{array}{l}\text { Patient } \\
\text { No. }\end{array}$} & \multirow[t]{2}{*}{$\operatorname{Sex}$} & \multirow[t]{2}{*}{$\begin{array}{l}\text { Age } \\
(y r)\end{array}$} & \multirow[t]{2}{*}{$\begin{array}{l}\mathrm{Hb} \\
(\mathrm{g} / \mathrm{l} 00 \mathrm{ml})\end{array}$} & \multirow{2}{*}{$\begin{array}{l}\text { Serum } \\
\text { Vitamin } B_{12} \\
(p g / m l)\end{array}$} & \multirow{2}{*}{$\begin{array}{l}\text { Serum } \\
\text { Folate } \\
(\mathrm{ng} / \mathrm{ml})\end{array}$} & \multicolumn{2}{|c|}{$\begin{array}{l}\text { Vitamin } B_{12} \text { Absorption }(\% \text { dose per } \\
\text { litre serum or } 24-h r \text { urine) }\end{array}$} & \multirow[t]{2}{*}{$\begin{array}{l}\text { Fractional } \\
\text { Test Meal }\end{array}$} & \multirow[t]{2}{*}{$\begin{array}{l}\text { Stool Fat } \\
(\mathrm{g} / 24 \mathrm{hr})\end{array}$} & \multirow{2}{*}{$\begin{array}{l}\text { Xylose } \\
\text { Excretion } \\
(\mathrm{g} / 5 \mathrm{hr})\end{array}$} & \multirow[t]{2}{*}{$\begin{array}{l}\text { Jejunal } \\
\text { Mucosa }\end{array}$} \\
\hline & & & & & & $\begin{array}{l}\text { Histamine or } \\
\text { Pentagastrin }\end{array}$ & Intrinsic Factor & & & & \\
\hline 5 & $\mathbf{F}$ & 57 & $5 \cdot 5$ & 120 & 0.6 & 0.5 & & Acid & 9 & $1 \cdot 6$ & \\
\hline 6 & $\mathbf{M}$ & 23 & $4 \cdot 4$ & 75 & 0.5 & 0.3 & & Acid & 9 & $4 \cdot 0$ & SVA \\
\hline 7 & $\mathbf{F}$ & 56 & 10.0 & 80 & 0.7 & 1.0 & & & 9 & & \\
\hline 8 & $\mathbf{M}$ & 67 & - $\quad 3.8$ & 20 & $2 \cdot 3$ & 0.3 & 0.4 & Acid & 13 & & \\
\hline 9 & $\mathbf{M}$ & 58 & $6 \cdot 1^{1}$ & 20 & $3 \cdot 8$ & 0.0 & 0.0 & No acid & 10 & 0.7 & SVA \\
\hline 10 & $\mathbf{F}$ & 23 & $4 \cdot 5$ & 75 & 0.6 & $0 \cdot 3$ & 0.5 & Acid & 15 & $1 \cdot 6$ & SVA \\
\hline 11 & $\mathbf{F}$ & 25 & 13.0 & 40 & 1.0 & 0.2 & 0.0 & & 74 & 0.6 & SVA \\
\hline 12 & $\mathbf{M}$ & 67 & $9 \cdot 3$ & 125 & 0.4 & $6 \cdot 0(u)^{2}$ & $10 \cdot 0(u)$ & No acid & 17 & & SVA \\
\hline 13 & $\mathbf{F}$ & 70 & 2.9 & 55 & 0.8 & $5 \cdot 0(u)$ & $5 \cdot 0(u)$ & Acid & 8 & & PVA \\
\hline 14 & $\mathbf{F}$ & 57 & $10 \cdot 2$ & 145 & 0.7 & 0.3 & & & 31 & $1 \cdot 8$ & SVA \\
\hline 15 & $\mathbf{M}$ & 54 & 10.4 & 100 & 0.4 & 0.2 & 0.3 & & 39 & 0.5 & SVA \\
\hline 16 & $\mathbf{F}$ & 51 & $10 \cdot 2^{1}$ & 140 & $1 \cdot 7$ & 1.0 & & & 13 & $0 \cdot 8$ & \\
\hline
\end{tabular}

Table II Details of patients with idiopathic steatorrhoea

${ }^{1}$ Typical blood picture of hyposplenism ${ }^{z} u=$ urine tested

'PVA = partial villous atrophy SVA $=$ subtotal villous atrophy

\begin{tabular}{|c|c|c|c|c|c|c|c|}
\hline \multirow{2}{*}{$\begin{array}{l}\text { Patient } \\
\text { No. }\end{array}$} & \multirow[t]{2}{*}{$\operatorname{Sex}$} & \multirow{2}{*}{$\begin{array}{l}\text { Age } \\
(y r)\end{array}$} & \multirow{2}{*}{$\begin{array}{l}\mathrm{Hb} \\
(\mathrm{g} / 100 \mathrm{ml})\end{array}$} & \multirow{2}{*}{$\begin{array}{l}\text { Serum } \\
\text { Vitamin } B_{12} \\
(\mathrm{pg} / \mathrm{ml})\end{array}$} & \multirow{2}{*}{$\begin{array}{l}\text { Serum Folate } \\
(\mathrm{ng} / \mathrm{ml})\end{array}$} & Vitamin $B_{12}$ Absorption ( $\%$ dose per litre serum or $24-h r$ urine) & \multirow{2}{*}{$\begin{array}{c}\text { Fractional } \\
\text { Test Meal }\end{array}$} \\
\hline & & & & & & Histamine or Pentagastrin & \\
\hline 17 & $\mathbf{F}$ & 56 & $7 \cdot 0$ & 30 & 1.4 & 0.8 & \\
\hline 18 & $\mathbf{F}$ & 30 & $5 \cdot 0$ & 20 & 0.8 & $28 \cdot 0(u)$ & Acid \\
\hline 19 & $\mathbf{M}$ & 78 & $4 \cdot 4$ & 80 & 0.5 & 0.4 & No acid \\
\hline 20 & $\mathbf{F}$ & 76 & $8 \cdot 0$ & 130 & $1 \cdot 3$ & 0.7 & \\
\hline 21 & $\mathbf{F}$ & 43 & $10 \cdot 3$ & 60 & $1 \cdot 0$ & 0.5 & Acid \\
\hline 22 & $\mathbf{F}$ & 73 & $7 \cdot 0$ & 75 & $1 \cdot 3$ & 0.7 & Acid \\
\hline 23 & $\mathbf{F}$ & 61 & $6 \cdot 4$ & 85 & 0.2 & 0.6 & Acid \\
\hline 24 & $\mathbf{M}$ & 59 & $5 \cdot 0$ & 120 & 0.4 & 0.6 & Acid \\
\hline 25 & $\mathbf{F}$ & 35 & $11 \cdot 3$ & 145 & $1 \cdot 5$ & $1 \cdot 2$ & No acid \\
\hline 26 & $\mathbf{M}$ & 61 & $9 \cdot 0$ & 140 & 1.8 & $16 \cdot 0(u)^{i}$ & No acid \\
\hline 27 & $\mathbf{M}$ & 49 & $8 \cdot 1$ & 130 & 1.5 & $26 \cdot 0(u)$ & No acid \\
\hline 28 & $\mathbf{F}$ & 81 & $5 \cdot 7$ & 75 & 0.4 & $16 \cdot 0(u)$ & \\
\hline 29 & $\mathbf{F}$ & 64 & 11.9 & 80 & $1 \cdot 2$ & $14 \cdot 0(u)$ & \\
\hline 30 & $\mathbf{F}$ & 74 & $8 \cdot 7$ & 145 & $1 \cdot 1$ & $1 \cdot 2$ & \\
\hline 31 & $\mathbf{M}$ & 67 & $4 \cdot 0$ & 130 & 1.6 & 0.4 & \\
\hline 32 & $\mathbf{M}$ & 70 & $4 \cdot 8$ & 45 & 0.5 & 1.0 & No acid \\
\hline 33 & $\mathbf{F}$ & 64 & $7 \cdot 3$ & 45 & 0.7 & 0.5 & Acid \\
\hline 34 & $\mathbf{F}$ & 80 & 4.0 & 140 & 0.6 & 0.6 & No acid \\
\hline
\end{tabular}

Table III Details of patients with nutritional folic acid deficiency

$\mathbf{1} \mathbf{u}=$ urine tested 


\begin{tabular}{|c|c|c|c|c|c|c|c|}
\hline \multirow{2}{*}{$\begin{array}{l}\text { Patient } \\
\text { No. }\end{array}$} & \multirow[t]{2}{*}{ Sex } & \multirow{2}{*}{$\begin{array}{l}\text { Age } \\
\text { (yr) }\end{array}$} & \multirow{2}{*}{$\begin{array}{l}\mathrm{Hb} \\
(\mathrm{g} / 100 \mathrm{ml})\end{array}$} & \multirow{2}{*}{$\begin{array}{l}\text { Serum Vitamin } B_{12} \\
(p g / m l)\end{array}$} & \multirow{2}{*}{$\begin{array}{l}\text { Serum Folate } \\
(n g / m l)\end{array}$} & \multicolumn{2}{|c|}{ Vitamin $B_{12}$ Absorption ( $\%$ dose per litre serum or $24-h r$ urine) } \\
\hline & & & & & & Histamine or Pentagastrin & Intrinsic Factor \\
\hline $\begin{array}{l}35 \\
36 \\
37 \\
38\end{array}$ & $\begin{array}{l}\mathbf{F} \\
\mathbf{F} \\
\mathbf{M} \\
\mathbf{M}\end{array}$ & $\begin{array}{l}71 \\
62 \\
60 \\
67\end{array}$ & $\begin{array}{r}9.9 \\
9.9 \\
10.4 \\
5.0\end{array}$ & $\begin{array}{r}30 \\
30 \\
15 \\
100\end{array}$ & $\begin{array}{l}3 \cdot 8 \\
7 \cdot 1 \\
5 \cdot 1 \\
1 \cdot 5\end{array}$ & $\begin{array}{l}8 \cdot 0(u)^{1} \\
3 \cdot 0(u) \\
0 \cdot 2 \\
5 \cdot 0(u)\end{array}$ & $\begin{array}{l}19 \cdot 0(u) \\
11 \cdot 0(u)\end{array}$ \\
\hline
\end{tabular}

Table IV Details of patients with megaloblastic anaemia following partial gastrectomy

${ }^{1} \mathbf{u}=$ urine tested

in the other two patients (cases 8 and 9). In both these patients the serum vitamin $B_{12}$ was only $20 \mathrm{pg}$ per ml, vitamin $B_{12}$ absorption was impaired, and vitamin $\mathbf{B}_{12}$ therapy produced a complete haematological response without any subsequent fall in the serum folate level. The initial indications that these two patients might have idiopathic steatorrhoea rather than pernicious anaemia were that they both had moderate diarrhoea, one (case 8) had free acid in the gastric juice and the other (case 9) had the typical blood picture of hyposplenism.

\section{MEGALOBLASTIC ANAEMIA DUE TO}

NUTRITIONAL FOLATE DEFICIENCY

This is in some respects an unsatisfactory diagnosis, as it depends on the exclusion of all other causes of megaloblastic anaemia and the demonstration of an inadequate dietary intake. The 18 patients in this group had no clinical or radiological evidence of steatorrhoea, but, as only two had a small intestinal mucosal biopsy, some cases of occult coeliac disease may possibly be included. All described a poor diet, and recovery was good on treatment with folic acid alone in eight patients and with folic acid and vitamin $B_{12}$ in seven patients. The other three patients showed a good initial response to folic acid therapy, but they ultimately deteriorated and were found to have carcinomas of the bronchus (case 24) caecum (case 27), and stomach (case 34).

The details of these patients are shown in Table III. The serum folate was, of course, low in all of them, the mean level being $1.0 \mathrm{ng}$ per $\mathrm{ml}$. Vitamin $B_{12}$ absorption was normal in 16 patients and slightly impaired in two. The serum vitamin $\mathbf{B}_{12}$ was below $90 \mathrm{pg}$ per $\mathrm{ml}$ in 10 patients, in four of whom it was below $50 \mathrm{pg}$. We observed the effect of folic acid therapy on the serum vitamin $B_{12}$ level in three patients (cases 18, 21, and 23) and in each case it rose slowly to within the normal range.

MEGALOBLASTIC ANAEMIA FOLLOWING PARTIAL GASTRECTOMY

The details of these four patients are shown in Table IV. There were three patients with a normal serum folate and a very low vitamin $B_{12}$ level. The other patient (case 38) had a low serum folate and a vitamin $B_{12}$ level of $100 \mathrm{pg}$ per $\mathrm{ml}$.

MEGALOBLASTIC ANAEMIA ASSOCIATED WITH ANTICONVULSANT THERAPY

One patient, a man aged 42, was on treatment with phenobarbitone, phenytoin, and primidone, and he was also taking a very poor diet. The serum folate was $0.9 \mathrm{ng}$ and the vitamin $B_{12} 85 \mathrm{pg}$ per $\mathrm{ml}$. There was free acid in the gastric juice and the vitamin $\mathrm{B}_{12}$ absorption test showed $0.6 \%$ administered radioactivity per litre of serum. Radiographs of the gastrointestinal tract and jejunal mucosal biopsy were normal. After treatment with folic acid for two months the serum vitamin $B_{12}$ had risen to $180 \mathrm{pg}$ per $\mathrm{ml}$.

\section{Discussion}

We included in this investigation all patients attending Sefton General Hospital with a macrocytic anaemia and a low serum vitamin $B_{12}$, provided that they had had a vitamin $\mathbf{B}_{12}$ absorption test and a suitable sample of serum for folate assay had been obtained. The inclusion of patients was as complete as possible, but some selection could not be avoided. Samples of serum for folate assay would tend to be collected more often from patients with serum vitamin $\mathbf{B}_{12}$ levels above the usual pernicious anaemia range, but, on the other hand, several patients with a low serum folate were not included, as they had not had a vitamin $\mathbf{B}_{12}$ absorption test. In spite of the fact that the patients were not entirely unselected, the value of a routine serum folate assay is emphasized by our finding a low folate in 34 $(38 \%)$ patients, $29(32 \%)$ of whom had anaemia due primarily to folate deficiency. These included 18 patients with nutritional folate deficiency, 10 with idiopathic steatorrhoea, and one on anticonvulsant therapy.

Low serum vitamin $\mathbf{B}_{12}$ levels were observed in $47 \%$ of patients with megaloblastic anaemia due to folate deficiency, and $10 \%$ of these had levels below $100 \mathrm{pg}$ per $\mathrm{ml}$ (Mollin et al, 1962). Our results have been similar, and our 18 patients with nutritional 
folate deficiency formed $40 \%$ of the total group of such cases. The cause of the low serum vitamin $B_{12}$ levels is uncertain in both these patients and the three patients with idiopathic steatorrhoea, who had normal vitamin $\mathbf{B}_{12}$ absorption. Previous observations on the effect of folic acid therapy on serum vitamin $B_{12}$ levels have been conflicting. The levels rose in one group of patients (Mollin et al, 1962) whereas they fell in another group on anticonvulsant therapy (Hunter, Barnes, and Matthews, 1969). Our patients with very low serum vitamin $B_{12}$ levels were usually treated with vitamin $B_{12}$ but we were able to study the effect of folic acid therapy on serum levels below $90 \mathrm{pg}$ per $\mathrm{ml}$ in four patients, three with nutritional folate deficiency and one taking anticonvulsant drugs; in each case the serum vitamin $B_{12}$ level slowly rose to within the normal range.

Occasionally the anaemia in patients with a low serum folate is due primarily to vitamin $B_{12}$ deficiency, the incidence of such cases in our group being five $(15 \%)$ out of 34 . One of these patients had had a partial gastrectomy, and the other four pernicious anaemia. Low serum folates occurred in $7.5 \%$ of the 54 patients with pernicious anaemia, an incidence close to the $10 \%$ reported by Chanarin (1969). The five patients with low serum folates had serum vitamin $B_{12}$ levels $(40,60,65,90$, and $100 \mathrm{pg} / \mathrm{ml})$ above the mean level of $35 \mathrm{pg}$ per $\mathrm{ml}$ in the pernicious anaemia and partial gastrectomy patients. Experimental evidence suggests that the low serum folates in gastrectomized subjects are the results of dietary deficiency (Markkanen, 1968). This may also explain the folate deficiency in pernicious anaemia as over one third of pernicious anaemia patients have anorexia and marked loss of weight (Seaton and Goldberg, 1960). Our four patients were anorexic, and as they were multiparous females, their body folate stores may have been depleted before the onset of pernicious anaemia. Their appetites improved immediately and the serum folates rose to normal levels within a few months of starting vitamin $\mathbf{B}_{12}$ therapy.

A raised serum folate only occurred in pernicious anaemia (Fig. 2). A normal folate level indicated impaired vitamin $B_{12}$ absorption, but six of the $\mathbf{4 8}$ patients in this group did not have pernicious anaemia. They included three patients who had had a partial gastrectomy, one patient reported previously (Forshaw, 1969) in whom the impaired vitamin $B_{12}$ absorption was corrected by vitamin $\mathrm{B}_{12}$ treatment, and two patients with idiopathic steatorrhoea. The last two are of particular interest as folate deficiency has been regarded as almost invariable in idiopathic steatorrhoea (Waters, 1963; Hoffbrand, Newcombe, and Mollin, 1966; Magnus, 1966). In a group of 28 patients with idiopathic steatorrhoea we found that these were the only two without evidence of folate deficiency (Forshaw, 1970). Both patients had very low serum vitamin $B_{12}$ levels with impaired vitamin $B_{12}$ absorption, and they made a complete haematological recovery on vitamin $\mathbf{B}_{12}$ therapy without a subsequent fall in the serum folate level. Impaired vitamin $B_{12}$ absorption is an indication that the mucosal damage has spread to the distal segments of the small bowel, and a direct correlation between the impairment of vitamin $\mathbf{B}_{12}$ absorption and the severity of the steatorrhoea has been observed (Stewart, Pollock, Hoffbrand, Mollin, and Booth, 1967). However, our two patients only had mild diarrhoea and steatorrhoea, and we were unable to confirm a definite association between vitamin $\mathbf{B}_{12}$ absorption and stool fat excretion in 23 patients with idiopathic steatorrhoea (Forshaw, 1970).

\section{References}

Chanarin, I. (1969). The Megaloblastic Anaemias, p. 306. Blackwell, Oxford.

Forshaw, J. (1969). Effect of vitamin $B_{12}$ and folic acid deficiency on small intestinal absorption. J. clin. Path., 22, 551-553.

Forshaw, J. (1970). Unpublished observations.

Gottlieb, C., Lau, K.-S., Wasserman, L. R., and Herbert, V. (1965). Rapid charcoal assay for intrinsic factor (IF), gastric juice unsaturated $B_{12}$ binding capacity antibody to IF, and serum unsaturated $\mathbf{B}_{1}$, binding capacity. Blood, 25, 875-884.

Harwood, L., and Forshaw, J. (1967). Vitamin $\mathbf{B}_{12}$ absorption studies: effect of parenteral non-radioactive vitamin $B_{12}$ on serum level of ${ }^{57}$ Co vitamin $B_{12}$ J. clin. Path., 20, 687-688.

Hoff brand, A. V., Newcombe, B. F. A., and Mollin, D. L. (1966) Method of assay of red cell folate activity and the value of the assay as a test for folate deficiency. J. clin. Path., 19, 17-28.

Hunter, R., Barnes, J., and Matthews, D. M. (1969). Effect of folicacid supplement on serum-vitamin-B $B_{12}$ levels in patients on anticonvulsants. Lancet, 2, 666-667.

Magnus, E. M. (1966). Low serum and red cell folate activity in adult celiac disease. Amer. J. dig. Dis., NS, 11, 314-319.

Markkanen, T. (1968). Absorption tests with natural folate material in controls and in gastrectomized patients. Amer. J. clin. Nutr., 21, 473-481.

Matthews, D. M. (1962). Observations on the estimation of serum vitamin $\mathrm{B}_{12}$ using lactobacillus leichmannii. Clin. Sci., 22, 101111.

Mollin, D. L., Waters, A. H., and Harriss, E. (1962). Clinical aspects of the metabolic interrelationships between $B_{18}$ folic acid and vitamin $B_{12}$. In Vitamin $B_{12}$ und intrinsic factor, 2. europäisches Symposion, Hamburg, 1961, edited by H. C. Heinrich, pp. 737 755. Enke, Stuttgart.

Schilling, R. F. (1953). Intrinsic factor studies. II. The effect of gastric juice on the urinary excretion of radioactivity after the oral administration of radioactive vitamin $\mathbf{B}_{12}$. J. Lab. clin. Med., 42, 860-866.

Seaton, D. A., and Goldberg, A. (1960). Weight-loss in pernicious anaemia. Lancet, 1, 1002-1004.

Spray, G. H. (1964). Microbiological assay of folic acid activity in human serum. J. clin. Path., 17, 660-665.

Stewart, J. S., Pollock, D. J., Hoffbrand, A. V., Mollin, D. L., and Booth, C. C. (1967). A study of proximal and distal intestinal structure and absorptive function in idiopathic steatorrhoea. Quart. J. Med., NS, 36, 425-444.

Taylor, K. B., Roitt, I. M., Doniach, D., Couchman, K. G., and Shapland, C. (1962). Autoimmune phenomena in pernicious anaemia: gastric antibodies. Brit. med. J., 2, 1347-1355.

Waters, A. H. (1963). Folic Acid Metabolism in the Megaloblastic Anaemias. PhD Thesis, London. 